\title{
Integrasi Sistem Pengawasan Kesehatan Jembatan dengan Sistem Pengawasan Lalu Lintas
}

\section{(The Integration of Bridge Health Monitoring System with Traffic Monitoring System)}

\author{
Muhammad Satria Wibawa ${ }^{1}$, Achmad Irjik Ubay ${ }^{1}$, Seno Adi Putra ${ }^{1}$, Alvi Syahrina ${ }^{1}$
}

\begin{abstract}
Bridge health monitoring system is a real-time data collection system that consists of components, responses, changes, and the construction process of bridge structures. This system aims to help assessing the structural security risks that could damage to the bridge structure by utilizing Wireless Sensor Network (WSN) as data retrieval. This system has a focus on the structure parameters of the bridge, but does not pay attention to vehicle factors, such as vehicle weight, vehicle patterns, and types of vehicles that pass on the bridge, which can also be factors of the bridge's health assessment. Another system, namely a traffic control system, measures vehicle weight using Weight in Motion (WIM). It can be used to obtain vehicle factors, especially vehicle weight, that also helps in assessing bridge health. This paper proposes the integration of these two systems in order to create a system that can measure health of bridge structures, as well as monitor the weight of the vehicle. Through this integration, it is possible to manage WSN sleep and wake time which helps saving energy. Experimental result shows that the system can measure natural frequencies close to the value of Finite Element Analysis (FEA), showing the validity of the developed system.
\end{abstract}

Intisari-Sistem pengawasan kesehatan jembatan adalah sistem pengumpulan data waktu-nyata yang terdiri atas komponen, respons, perubahan, dan proses konstruksi struktur jembatan. Tujuan sistem adalah untuk membantu menilai risiko keamanan struktural yang dapat merusak struktur jembatan dengan memanfaatkan Wireless Sensor Network (WSN) dalam pengambilan data. Sistem ini berfokus pada parameter struktur jembatan, tetapi tidak memperhatikan faktor kendaraan seperti berat kendaraan, pola kendaraan, dan jenis kendaraan yang melewati jembatan, yang juga dapat menjadi faktor penilaian kesehatan jembatan. Sistem lain, yaitu sistem kontrol lalu lintas, mengukur berat kendaraan menggunakan Weight in Motion (WIM). WIM dapat digunakan untuk memperoleh faktor-faktor kendaraan, terutama berat kendaraan, yang juga membantu dalam menilai kesehatan jembatan. Makalah ini mengusulkan integrasi kedua sistem untuk menciptakan sistem yang dapat mengukur kesehatan struktur jembatan serta memantau berat kendaraan. Melalui integrasi ini, dimungkinkan untuk mengelola waktu tidur dan bangun WSN yang membantu menghemat energi. Hasil eksperimen menunjukkan bahwa sistem dapat mengukur frekuensi

\footnotetext{
${ }^{1}$ Program Studi Sistem Informasi, Fakultas Rekayasa Industri Universitas Telkom, Jl. Telekomunikasi Terusan Buah Batu Indonesia 40257, Bandung, INDONESIA (telp: (022) 7566456; $e$ mail: $\quad$ satriawibawa@student.telkomuniversity.ac.id, aiubay@student.telkomuniversity.ac.id,

adiputra@telkomuniversity.ac.id, syahrina@telkomuniversity.ac.id)
}

alami mendekati nilai Finite Element Analysis (FEA) yang menunjukkan validitas sistem yang dikembangkan.

Kata Kunci-Sistem Pengawasan Kesehatan Struktur, Sistem Pengawasan Lalu Lintas, Jaringan Sensor Nirkabel, Weight in Motion, Berat Kendaraan, Nilai Kesehatan Jembatan.

\section{PENDAHULUAN}

Infrastruktur jembatan dibangun sebagai rute yang menghubungkan dua tempat yang terpisah karena faktor alam. Faktor struktur jembatan yang sudah menua, kondisi lingkungan tak menentu, dan beban kendaraan yang melalui jembatan dapat menimbulkan kerusakan jembatan. Agar risiko kerusakan jembatan dapat diminimalkan, diperlukan pengawasan atas dampak lingkungan seperti temperatur, kelembapan, dan beban kendaraan berat. Pengawasan perlu dilakukan secara rutin dan hasil evaluasi dapat diperoleh melalui pemanfaatan teknologi jaringan sensor nirkabel (Wireless Sensor Network/WSN).

Sistem pengawasan kesehatan struktur adalah sistem yang mengumpulkan secara nyata, dalam interval waktu yang teratur, data yang terkait dengan komponen struktural dalam fabrikasi, manufaktur, respons struktur, perubahan struktur, dan proses konstruksi. Sistem ini dapat digunakan untuk menguji risiko keamanan struktur yang berdampak pada kerusakan atau deformasi struktur [1]. Hal yang diperlukan adalah metode yang efektif dan efisien dalam pengumpulan dan pemrosesan data struktur untuk pengukuran tingkat kesehatannya yang berhubungan dengan frekuensi alamiahnya. Untuk memperoleh data terkini, diperlukan sistem sensor pengambilan data vibrasi struktur secara otomatis.

Sistem pengawasan lalu lintas adalah sistem pengawasan yang terkait dengan pengaturan lalu lintas, seperti pengendalian pelanggaran lalu lintas, pengendalian pencegahan kecelakaan lalu lintas, dan pendeteksian pengemudi yang berpotensi membahayakan [2]. Sistem ini biasanya menggunakan kamera untuk mengidentifikasi informasi kendaraan yang melintas. Jika dilihat dari sisi dampak terhadap struktur jalan yang dilalui, sistem ini bermanfaat untuk mendeteksi beban kendaraan yang melalui jalan tersebut. Pendeteksian ini ditujukan untuk pengendalian pelanggaran lalu lintas, khususnya yang berhubungan dengan pelanggaran beban muatan yang melebihi ketentuan yang ada. Selain itu, pendeteksian ini juga berguna untuk memperoleh informasi berat beban dan kendaraan yang melalui jalan tersebut. Jadi, sistem identifikasi beban kendaraan, pola kendaraan, dan jenis kendaraan diperlukan untuk 
meningkatkan akurasi penilaian kesehatan struktur maupun untuk pengawasan lalu lintas.

Berbagai penelitian sistem kesehatan struktur jembatan telah dilakukan dengan penerapan analisis Fast Fourier Transform (FFT), identifikasi puncak amplitudo frekuensi, dan identifikasi pola getar jembatan (mode shape) menggunakan WSN [3]. Untuk mendapatkan kualitas pemrosesan data yang baik, pada sistem sensor dikembangkan konsep actuator network [4] dan komputasi di dalam WSN untuk peningkatan kualitas pemro-sesan data [5], [6]. Pemrosesan data di WSN dan peranti keras yang mendukung sistem pengawasan kesehatan struktur jemba-tan telah dikembangkan [7]-[9] dengan kerangka kerja IoT untuk pengawasan kesehatan struktur [1].

Sistem pengawasan lalu lintas telah dikembangkan ke arah penerapan analisis respons jembatan terhadap perilaku arus lalu lintas dengan berbagai muatan atau selama peristiwa kritis yang menyebabkan pola getaran di luar batas normal [10]. Untuk mengukur berat dan jenis kendaraan, dapat digunakan sensor Weight in Motion (WIM) [11]. Di sini sistem sensor terintegrasi dalam paradigma IoT [12], yang mencakup pengembangan WIM untuk pengambilan data kendaraan [13] dan pengembangan sistem pengolahan dan pemrosesan data [14].

Berbeda dengan penelitian-penelitian sebelumnya, makalah ini mencoba mengintegrasikan sistem pengawasan kesehatan jembatan berbasis WSN dan sistem pengawasan lalu lintas berbasis WIM untuk mengidentifikasi berat kendaraan. Hasil penelitian sebelumnya digunakan sebagai referensi, yang pada makalah ini dilakukan proses modifikasi untuk mengintegrasikan sistem. Integrasi ini menghasilkan sebuah sistem yang tidak hanya dapat mengukur kesehatan struktur jembatan, tetapi dapat juga menghitung berat dan kecepatan kendaraan yang melintas. Jadi, sistem dapat digunakan untuk pengawasan berat dan jenis kendaraan. Hasil integrasi ini juga dapat menghemat energi baterai simpul sensor karena sebelumnya sensor bekerja terus menerus tanpa terkendali. Melalui pemanfaatan sensor WIM untuk mendeteksi kendaraan yang melintas, dimungkinkan dilakukannya penerapan mode sleep and wakeup pada WSN.

Kontribusi utama makalah ini adalah terciptanya model kebutuhan, model arsitektur, model rancangan, dan model solusi sistem penilaian kondisi kesehatan jembatan berdasarkan respons dinamik ketika dilalui kendaraan berat. Sistem menggunakan WSN yang diintegrasikan dengan sistem pengawasan lalu lintas berbasis WIM untuk identifikasi berat dan laju kendaraan beserta pengaturan waktu kerja WSN. Makalah ini juga mengusulkan sistem pengukuran tingkat kesehatan jembatan secara otomatis menggunakan teknologi WSN.

Makalah ini dibagi menjadi beberapa bagian sebagai berikut. Bagian pertama merupakan pendahuluan. Bagian kedua mendeskripsikan Structural Health Monitoring System (SHMS) dan Traffic Monitoring System (TMS). Bagian ketiga mendeskripsikan usulan integrasi sistem dan bagian keempat adalah hasil pengujian melalui eksperimen. Selanjutnya, bagian kelima adalah perbandingan dengan penelitian terdahulu, sedangkan bagian terakhir berisi kesimpulan.

\section{STRUCTURAL HEALTH MoNitoring SYSTEM (SHMS) DAN TRAFFIC MONITORING SYSTEM (TMS)}

\section{A. Structural Health Monitoring (SHM)}

Structural Health Monitoring (SHM) adalah proses penerapan deteksi kerusakan dan strategi karakterisasi struktur pada rekayasa struktur [1]. Tujuan aplikasi SHM adalah untuk mengumpulkan data secara nyata atau dalam interval waktu tertentu terkait dengan komponen struktural yang terlibat dalam fabrikasi, manufaktur, dan proses konstruksi sehingga teridentifikasi risiko keamanan struktur [1]. SHM memungkinkan penilaian struktur secara waktu nyata dari struktur dengan cara terus mengukur, menguraikan, dan mengendalikan parameter fisik-mekanik yang memiliki signifikansi yang relevan dalam karakterisasi perilaku struktural dan interaksinya dengan lingkungan. Melalui perhitungan, perbandingan, dan analisis respons struktur, SHM dapat berfungsi sebagai sistem peringatan darurat, sistem penilaian keamanan, dan sistem pendukung pemeliharaan struktur [15]. Pada WSN untuk SHM, sensor ditempatkan di berbagai lokasi di seluruh struktur. Sensor ini mengumpulkan informasi seperti percepatan getaran, beban, dan stress pada frekuensi pencuplikan data hingga 100 $\mathrm{Hz}[16]$.

Dalam SHM terdapat beberapa metode untuk melakukan deteksi kerusakan, seperti Non-Destructive Testing (NDT) methods, vibration-based damage detection methods, dan consideration of uncertainties [17]. Fokus makalah ini terletak pada penggunaan metode pendeteksian kerusakan bernama vibration-based damage detection methods yang merupakan metode identifikasi kerusakan melalui perubahan pola getaran. Metode ini telah dikembangkan pada premis yang umum terkait pengukuran kuantitas getaran, seperti response time-histories dan global vibration characteristics. Keduanya merupakan fungsi dari sifat fisik struktur (massa, redaman, batas kondisi, dan kekakuan) terhadap perubahan frekuensi ketika dilakukan pengukuran pergeseran frekuensi alami. Damage detection methods merupakan metode pendeteksian kerusakan pada struktur yang terdiri atas time domain-based atau analisis domain waktu dan frequency domain-based atau analisis domain frekuensi. Pada analisis domain waktu, data time series yang dikumpulkan dari simpul sensor langsung diproses untuk mengekstrak parameter modal. Teknik umum yang digunakan pada analisis domain waktu adalah auto-regressive moving average, Ibrahim time domain method, data-driven subspace identification, dan covariance matrix. Pada analisis domain frekuensi, data time series yang dikumpulkan lalu diubah dari domain waktu ke domain frekuensi melalui transformasi seperti Fast Fourier Transform (FFT) dan Wavelet Transform (WT). Teknik umum yang digunakan pada analisis domain frekuensi ialah peak picking, complex mode identification function, rational fraction polynomial, dan Hilbert-Huang transform based [18]. Makalah ini berfokus pada bagian analisis domain frekuensi melalui FFT dan menggunakan teknik peak picking. FFT merupakan suatu algoritme yang digunakan untuk merepresentasikan sinyal diskret dalam domain waktu dan domain frekuensi. Peak picking merupakan teknik umum untuk mengumpulkan data sensor dan eigen frequencies diidentifikasi di puncak plot respons frekuensi [17]. Eigen frequencies 
digunakan dalam ekstraksi frekuensi alami dan mode shape. Pada data akselerasi di domain frekuensi, metode peak picking digunakan untuk memilih amplitudo puncak dan frekuensi fundamental. Alasan penggunaan FFT dan peak picking adalah karena metode ini cepat dan cocok digunakan di WSN. Metode ini mengasumsikan bahwa frekuensi natural jembatan berkaitan erat dengan peak di respons frekuensi. Selain itu, FFT cocok untuk jembatan dengan respons getaran yang stationer atau jembatan dengan material homogen atau jembatan Single Degree of Freedom (SDOF). Jembatan SDOF adalah jembatan yang hanya memiliki satu gerak bebas. Prosedur investigasi penilaian respons dinamik kondisi jembatan terdiri atas empat langkah, yaitu membangun Finite Element Analysis (FEA), FFT, perancangan WSN, dan terakhir identifikasi perbedaan hasil FEA dan hasil yang diperoleh dari sistem yang dirancang [18].

\section{B. Traffic Monitoring System (TMS)}

Otomasi sudah menjadi bagian di hampir semua bidang industri, khususnya pengawasan. Otomasi di bidang pengawasan lalu lintas sangat dibutuhkan karena jumlah kendaraan di jalan mulai meningkat. Dengan semakin meningkatnya jumlah kendaraan, muncul tantangan untuk mengatur lalu lintas [10]. TMS merupakan sebuah sistem yang memberi saran pada sistem kendali perintah dan sistem persinyalan. Sistem ini menerima informasi tentang situasi lalu lintas saat ini [2]. Penggunaan sistem SHMS dan TMS dapat membantu manajemen lalu lintas. Selain itu, sistem SHMS dan TMS yang telah terintegrasi akan lebih efektif dalam mengidentifikasi kerusakan yang disebabkan oleh kendaraan yang melebihi beban [19]. TMS dapat menyediakan layanan yang berpotensi meningkatkan efisiensi dan keselamatan lalu lintas serta mengurangi waktu respons insiden lalu lintas. Untuk menyediakan layanan tersebut, TMS bergantung pada tiga fase utama, yaitu pengumpulan informasi, pemrosesan informasi, dan pengiriman layanan.

Pengumpulan informasi bertanggung jawab untuk mengumpulkan data terkait lalu lintas dari berbagai sumber, termasuk kendaraan, sensor di jalan, lampu lalu lintas, dan sumber web yang tersedia untuk umum. Data terkait lalu lintas dikumpulkan dari berbagai sensor bawaan. Data lalu lintas juga dapat diperoleh dari masyarakat seperti publikasi di sosial media. Pada fase pemrosesan informasi, dilakukan pengolahan untuk identifikasi atau memperkirakan beberapa bahaya lalu lintas. Dengan cara ini, pemrosesan informasi dapat dilakukan dengan infrastructure-free atau infrastructure-based. Pengiriman layanan menyediakan layanan berdasarkan bahaya lalu lintas yang diidentifikasi pada fase sebelumnya untuk mengendalikan dan meningkatkan efisiensi lalu lintas secara keseluruhan [19]. Pada penelitian integrasi SMHS dan TMS ini difokuskan penggunaan WIM untuk mendapatkan data berat dan laju kendaraan dan sebagai pengendali waktu WSN bekerja.

\section{USULAN INTEGRASI SISTEM}

\section{A. Arsitektur Umum}

Arsitektur umum yang diusulkan pada makalah ini melibatkan dua buah jenis sensor, yaitu sensor nirkabel

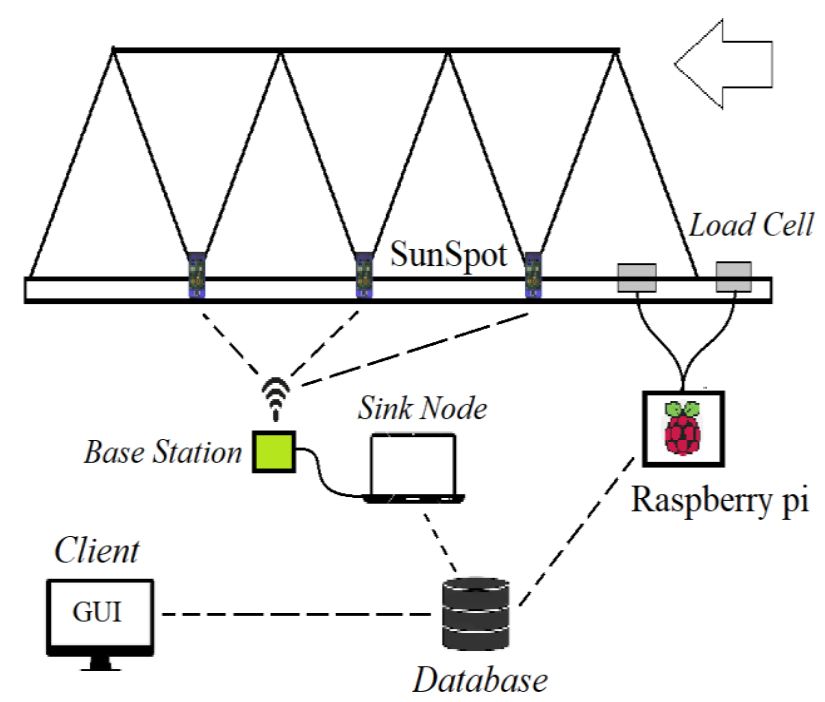

Gbr. 1 Arsitektur sistem.

SunSpot dan sensor load cell. Raspberry Pi digunakan sebagai koneksi load cell. Server basis data digunakan sebagai tempat penyimpanan data-data sejarah pengukuran. Simpul sink yang terhubung dengan basestation berfungsi menyampaikan perintah dan sebagai tempat penyimpanan data sementara dari sensor nirkabel SunSpot. Perangkat klien digunakan untuk menjalankan sistem atau sebagai antarmuka sistem dengan pengguna. Arsitektur ini diilustrasikan pada Gbr. 1 .

Load cell dipasang pada bagian masuk jembatan. Sensor load cell tersambung dengan HX711 yang berguna untuk mengonversi data analog ke digital. Proses tersebut dilakukan pada Raspberry Pi dengan tambahan proses perhitungan data berat dan kecepatan kendaraan. Kemudian, data dari Raspberry Pi dikirimkan ke basis data di simpul sink. Simpul sink selanjutnya memberi perintah untuk menyalakan sensor nirkabel SunSpot untuk melakukan pengambilan data akselerasi yang selanjutnya diproses menjadi data frekuensi dan amplitude. Setelah itu, data yang telah diproses oleh sensor nirkabel SunSpot dikirim ke server basis data supaya data rata-rata frekuensi alamiah jembatan, mode shape, kecepatan, dan berat kendaraan ditampilkan di perangkat klien.

Load cell dapat diatur agar data berat beban yang melintasi jembatan merepresentasikan berat yang sebenarnya terjadi di lingkungan nyata. Kemudian, pada bagian sensor SunSpot, jumlah sensor yang digunakan dapat disesuaikan dengan bentuk dan panjang jembatan. Jumlah sensor SunSpot merepresentasikan tingkat detail penggambaran mode shape, yaitu semakin banyak sensor SunSpot yang terpasang, semakin akurat mode shape. Arsitektur ini dapat diterapkan untuk jembatan SDOF satu bentang. Jika digunakan pada jembatan dua bentang, maka perlu adanya segmentasi atau cluster sensor node untuk pertimbangan cakupan radio.

\section{B. Model Kebutuhan Sistem}

Pemodelan kebutuhan sistem dilakukan berdasarkan kebutuhan yang harus dipenuhi sistem. Untuk menggambarkan kebutuhan sistem, digunakan diagram use case. Di sini digambarkan relasi antara pengguna dengan sistem. Diagram 


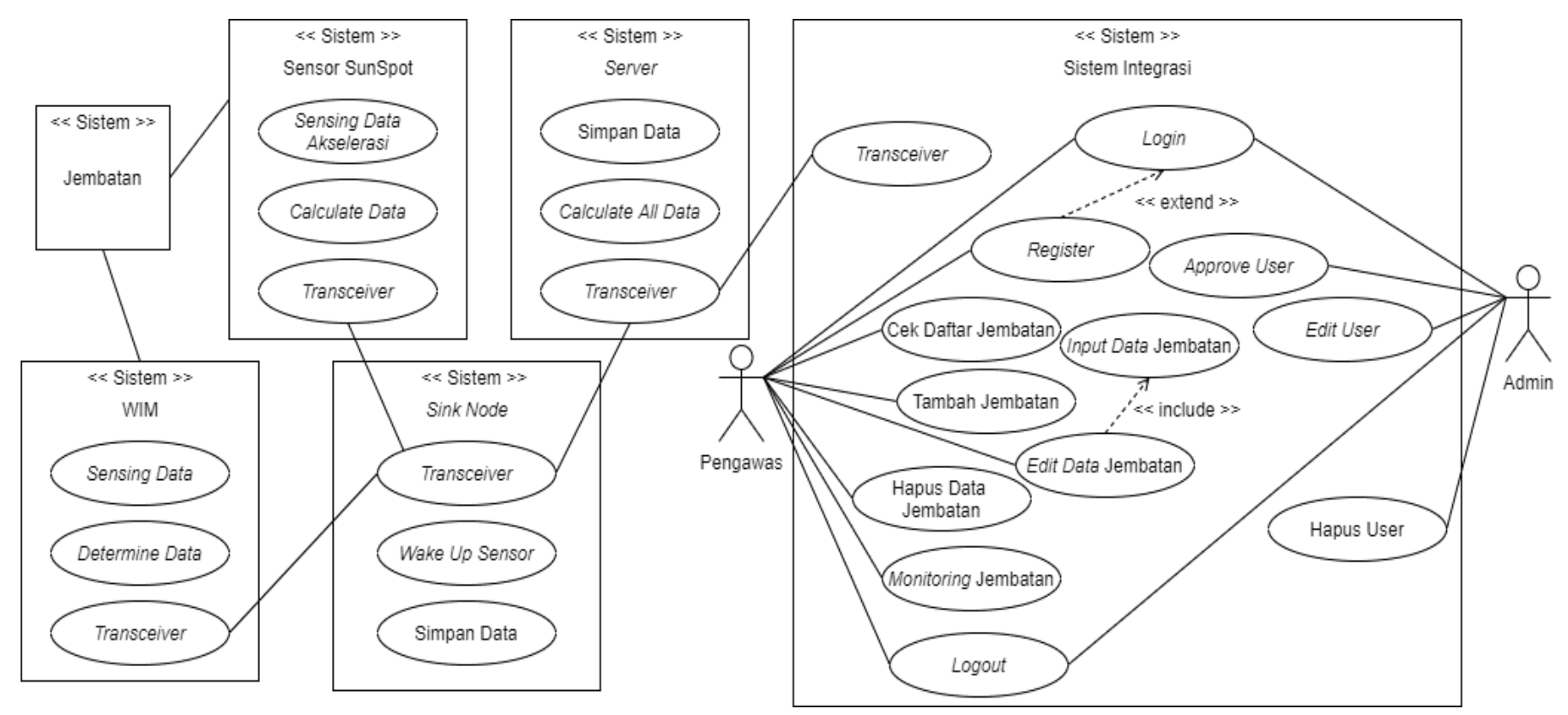

Gbr. 2 Diagram use case sistem pengawasan kesehatan jembatan dan lalu lintas.

use case ditunjukkan pada Gbr. 2, yang terdiri atas sistem jembatan, simpul sensor nirkabel SunSpot, WIM, simpul sink, server basis data, dan sistem integrasi.

Sistem jembatan merupakan objek jembatan yang diawasi menggunakan sistem sensor nirkabel SunSpot dan WIM. Sistem SunSpot merupakan sistem sensor yang dapat melakukan pengindraan data akselerasi getaran jembatan, FFT untuk mendapatkan frekuensi fundamental jembatan beserta puncak amplitudonya, dan transceiver sebagai media komunikasi antar sistem. Sistem WIM merupakan sensor yang melakukan pengindraan berat dan laju kendaraan yang melintas. WIM juga menentukan waktu simpul-simpul sensor nirkabel melakukan pengindraan dengan mempertimbangkan nilai threshold berat yang menyatakan bahwa kendaraan yang sedang melintasi perlu diobservasi dampaknya terhadap jembatan. WIM memiliki transceiver sebagai media komunikasi antar sistem. Simpul sink bekerja sama dengan WIM untuk menentukan simpul sensor SunSpot perlu dibangunkan atau tidak. Simpul sink juga bertugas untuk menghitung nilai rata-rata frekuensi natural jembatan dari semua data yang dihitung oleh simpul sensor nirkabel dan mengelola nilai amplitudo dari frekuensi tersebut sebagai bahan untuk menampilkan mode shape. Sama halnya dengan simpul-simpul lain, transceiver di sink berfungsi sebagai komunikasi antar sistem. Sistem server mengelola datadata yang dihasilkan selama pengukuran (average frequency, mode shape, berat kendaraan, kecepatan kendaraan, dan hasil rating).

Sistem integrasi adalah sistem yang berperan dalam menampilkan data dan informasi kepada pengguna seperti pengawas dan admin. Pengawas jembatan dapat berinteraksi dengan sistem, seperti melakukan login untuk masuk ke dalam sistem atau registrasi jika belum mempunyai hak akses, melihat data-data dan informasi jembatan-jembatan yang tersimpan di basis data, menambah data jembatan yang belum terdaftar, memperbarui data jembatan di dalam basis data, menghapus data jembatan dari basis data, mengawasi perilaku-perilaku jembatan, melakukan pengambilan keputusan dalam penanganan jembatan, dan logout untuk keluar dari aplikasi. Admin juga melakukan login untuk masuk ke dalam sistem, menyetujui pengguna yang registrasi ke sistem, memperbarui data pengguna, menghapus pengguna, dan logout untuk keluar aplikasi.

\section{Model Rancangan}

Pemodelan rancangan sistem menggambarkan sketsa atau rencana perilaku sistem. Model rancangan dibuat berdasarkan model kebutuhan sistem dengan melihat fungsionalnya. Model rancangan digambarkan dengan menggunakan diagram kelas. Pada diagram kelas terdapat beberapa hubungan atau ketergantungan kelas Tier2 dengan kelas MyMethod. Pada diagram kelas ini juga digambarkan asosiasi yang menunjukkan bahwa kelas tersebut berhubungan satu sama lain. Selain itu, terdapat hubungan agregasi yang menggambarkan relasi kepemilikan, seperti pada kelas DatabaseDemoHostApplication dan kelas SensorSampler, atau dengan kata lain, kelas DatabaseDemoHostApplication milik simpul sink memiliki kelas SensorSampler (sensor akselerometer). Kelas diagram juga menunjukkan adanya hubungan komposisi yang menggambarkan relasi kepemilikan yang bergantung satu sama lain. Di sini, jika satu kelas tidak bekerja, maka kelas yang berhubungan tidak akan bekerja. Contoh dari relasi ini adalah hubungan kelas SensorSampler dan kelas Receiver. Gambaran kelas diagram tersebut ditunjukkan pada Gbr. 3.

\section{Model Arsitektur}

Model arsitektur menjelaskan sistem yang terbagi ke dalam Client tier, Presentation tier, Business tier, dan Resources tier. Pada model arsitektur ini koneksi yang digunakan antar tier menggunakan komunikasi socket atau komunikasi tunnel (server Socket dan client socket) seperti pada komunikasi simpul sink (client socket) dengan server (server socket) dan 


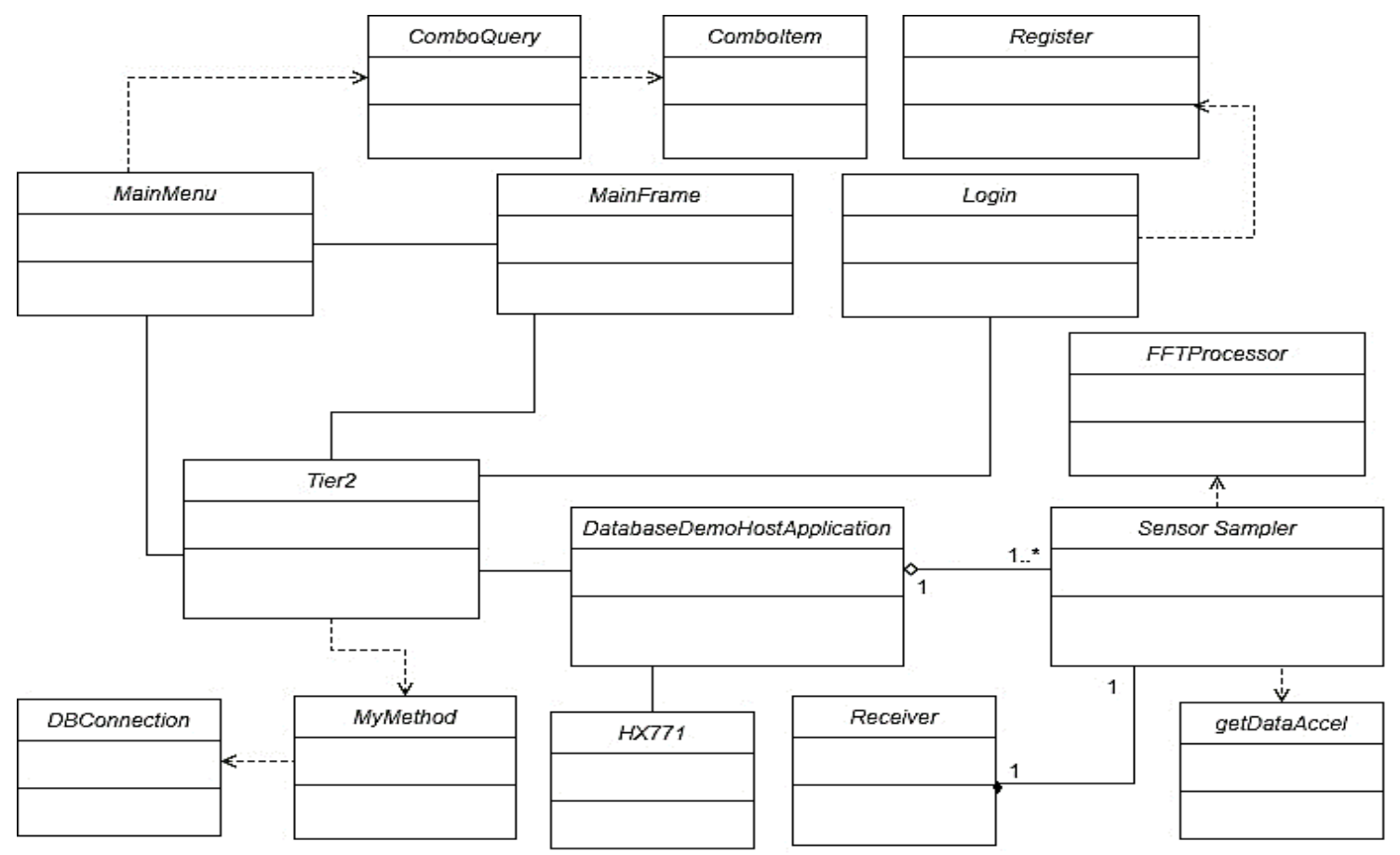

Gbr. 3 Model rancangan sistem.

TABEL I

SOLUSI TEKNOLOGI

\begin{tabular}{|c|c|c|c|c|c|c|c|}
\hline Layer & \multicolumn{2}{|c|}{ Client Tier } & $\begin{array}{c}\text { Presentation } \\
\text { Tier }\end{array}$ & \multicolumn{3}{|c|}{ Business Tier } & $\begin{array}{c}\text { Resources } \\
\text { Tier }\end{array}$ \\
\hline $\begin{array}{l}\text { Application } \\
\text { Platform }\end{array}$ & Sensor SunSpot & $\begin{array}{l}\text { Load } \\
\text { cell }\end{array}$ & $\begin{array}{l}\text { Integrasi } \\
\text { sistem }\end{array}$ & Simpul sink & $\begin{array}{l}\text { Aplikasi } \\
\text { server }\end{array}$ & Raspberry Pi & Tacom_ta.SQL \\
\hline $\begin{array}{l}\text { Upper } \\
\text { Platform }\end{array}$ & SunSpot API & Python 2.7 & Java SE 14 & Java JRE 6 & Java SE 14 & Python 2.7 & $\begin{array}{l}\text { JDBC } 7.0, \\
\text { MySQL } 8.0\end{array}$ \\
\hline $\begin{array}{l}\text { Lower } \\
\text { Platform }\end{array}$ & Squawk VM & ICINA114 & $\begin{array}{l}\text { Linux Ubuntu, } \\
\text { Windows } 10\end{array}$ & $\begin{array}{l}\text { Linux, } \\
\text { Windows } 7\end{array}$ & $\begin{array}{l}\text { Linux, } \\
\text { Windows } 7\end{array}$ & $\begin{array}{l}\text { Linux } \\
\text { Raspbian }\end{array}$ & $\begin{array}{l}\text { Linux, } \\
\text { WinServer } 2003\end{array}$ \\
\hline $\begin{array}{l}\text { Hardware } \\
\text { Platform }\end{array}$ & $\begin{array}{l}32 \text { bits } \\
\text { ARM920T } 180 \\
\text { MHz }\end{array}$ & $\begin{array}{l}\text { ATM } \\
\text { ega16 }\end{array}$ & $\begin{array}{l}\text { Intel E4xxx } \\
\text { Core } 2 \text { Duo }\end{array}$ & $\begin{array}{l}\text { Intel E4xxx } \\
\text { Core } 2 \text { Duo }\end{array}$ & $\begin{array}{l}\text { Intel E4xxx } \\
\text { Core } 2 \text { Duo }\end{array}$ & $\begin{array}{l}\text { Broadcom } \\
\text { BCM2837B0 } \\
\text { quad-core A53 64-bit }\end{array}$ & $\begin{array}{l}\text { Intel Core, atau } \\
\text { Xeon } 3 \mathrm{GHz}\end{array}$ \\
\hline
\end{tabular}

server (server socket) dengan antar muka pengguna grafis (client socket). Selain itu, terdapat pula komunikasi JDBC yang digunakan pada komunikasi basis data dengan server aplikasi dan simpul sink dengan basis datanya. Selanjutnya, terdapat komunikasi standar Python, yaitu koneksi standar yang digunakan ketika melakukan pengodean bahasa pemrograman Python. Komunikasi radiogram digunakan pada simpul sensor nirkabel dengan simpul sink.

Jika dilihat dari alurnya, model arsitektur ini diawali dengan load cell yang mendeteksi berat, lalu Raspberry Pi mengubah data menjadi data digital, kemudian mengirim data tersebut dan juga data status ke server aplikasi untuk disimpan di basis data. Karena data status berubah, maka server aplikasi memberitahu simpul sink bahwa terjadi perubahan status, lalu simpul sink membangunkan sensor SunSpot untuk melakukan pengindraan dan pemrosesan data. Selanjutnya, data-data dari simpul sensor dikirim ke simpul sink untuk dihitung rata-rata frekuensi natural jembatan dan puncak amplitudonya. Data tersebut dikirim ke server aplikasi untuk disimpan di basis data. Datadata yang tersimpan di basis data akan ditampilkan oleh antarmuka pengguna grafis supaya dilihat oleh pengguna. Mekanisme distribusi data ini ditunjukkan pada Gbr. 4.

\section{E. Model Solusi Teknologi}

Model Solusi berfokus kepada penggunaan teknologi berdasarkan model arsitektur dan model rancangan yang telah dibuat. Model solusi ini mendeskripsikan dukungan platform teknologi di dalam aplikasi atau sistem. Model ini bertujuan agar aplikasi atau sistem dapat dioptimalkan dengan pemanfaatan teknologi yang saat ini berkembang. Pada model solusi, setiap kerangka kerja peranti lunak yang digunakan dibagi berdasarkan kebutuhan dalam tier dan layer-nya. Model solusi yang digunakan ditunjukkan pada Tabel I.

\section{SIMULASI DAN EKSPERIMEN}

Eksperimen dilakukan pada jembatan miniatur test-bed yang telah dirancang sesuai dengan kaidah-kaidah dalam teknik sipil [18]. Pada jembatan test-bed ini dipasang sensor SunSpot dan sensor load cell yang berperan sebagai WIM. Spesifikasi sensor sesuai dengan model solusi teknologi yang diusulkan. 


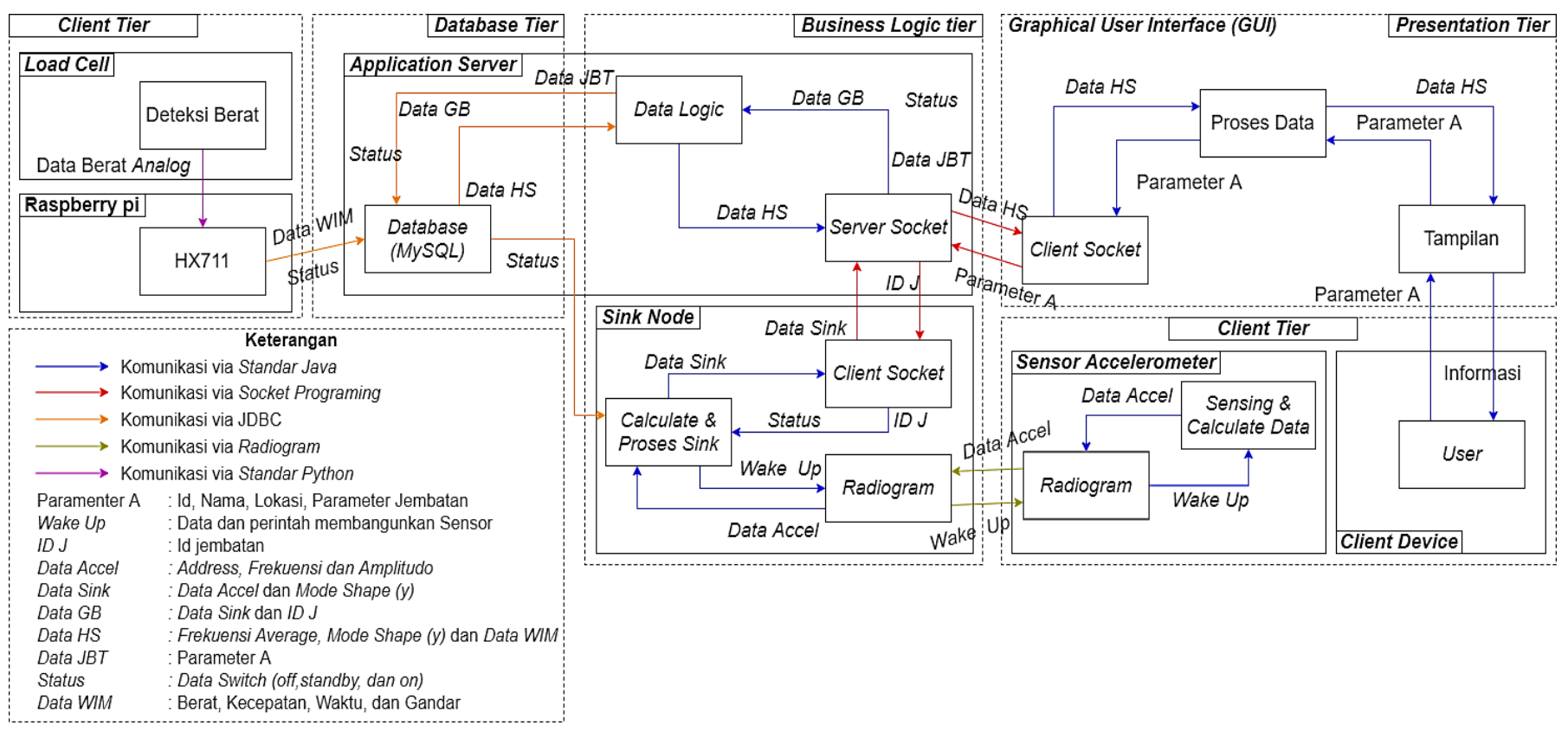

Gbr. 4 Model arsitektur sistem.

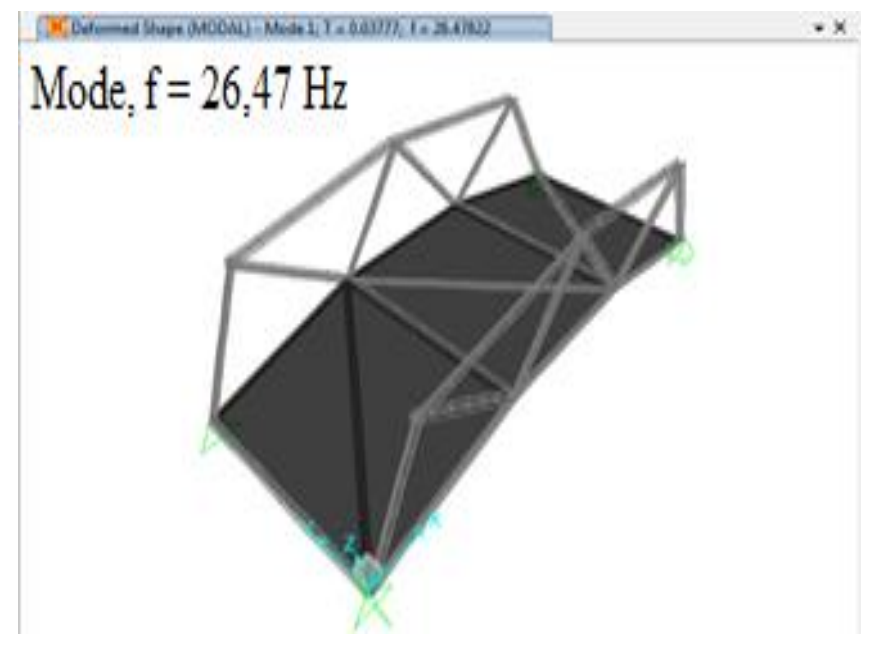

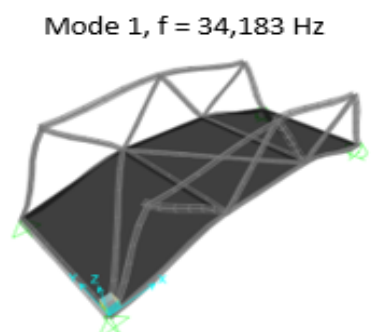

Mode $3, \mathrm{f}=62,839 \mathrm{~Hz}$

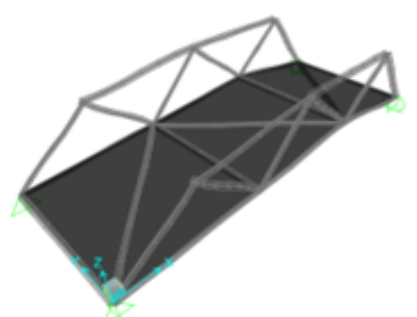

Mode 2, $\mathrm{f}=38,972 \mathrm{~Hz}$

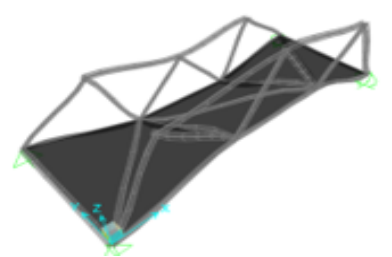

Mode $4, \dagger=82,949 \mathrm{~Hz}$

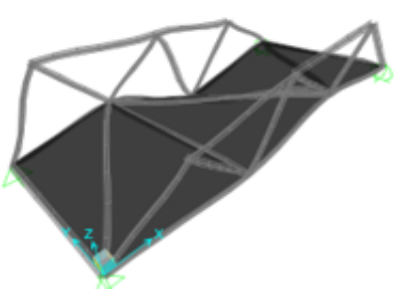

Gbr. 5 Simulasi dan finite element analysis.

\section{A. Jembatan Test-bed dengan Finite Element Analysis (FEA)}

Jembatan test-bed dirancang berdasarkan FEA dan dibangun menggunakan rangka dan pelat baja sebagai alasnya. Rancangan disimulasikan oleh perangkat lunak CSi Bridge Application 2017. Hasil rancangan diperlihatkan pada gambar Gbr. 5.

Jembatan test-bed yang dibangun merupakan jembatan dua bentang yang masing-masing bentang disusun dari rangka baja dengan profil siku ukuran $3 \mathrm{~cm}$ dengan tebal 1,5 $\mathrm{mm}$ dan pelat baja sebagai lantai jembatan dengan tebal pelat baja $2,5 \mathrm{~mm}$. Pelat sambung menggunakan pelat dengan ketebalan $4 \mathrm{~mm}$ dan baut penyambung berdiameter $8 \mathrm{~mm}$. Jembatan test-bed yang dirancang mampu menahan berat sendiri dan beban hidup sebesar $300 \mathrm{~kg}$ di tengah bentang jembatan dengan stress ratio terbesar yang terjadi pada rangka baja adalah 0,848 , sehingga jembatan mampu menahan beban statis sebesar $300 \mathrm{~kg}$. Analisis frekuensi pada CSi Bridge menghasilkan frekuensi natural pada empat mode pertama, yaitu Mode $1(34,183 \mathrm{~Hz})$, Mode $2(38,972 \mathrm{~Hz})$, Mode $3(62,839 \mathrm{~Hz})$, dan Mode $4(82,949$ $\mathrm{Hz})$. Untuk analisis dinamik, dilakukan analisis respons jembatan akibat beban kendaraan bergerak dengan kekakuan strukturnya dikurangi sampai dengan 0,6 kali, sehingga diperoleh frekuensi natural jembatan sekitar 26,47 Hz. Analisis statis dan dinamik ini ditunjukkan pada Gbr. 5.

\section{B. Pengujian Fungsionalitas}

Pengujian fungsionalitas merupakan pengujian fitur sistem. Fitur pada digambarkan pada Gbr. 6. Untuk aktor pengawas, terdapat fitur login, registrasi, tambah jembatan, edit jembatan, 

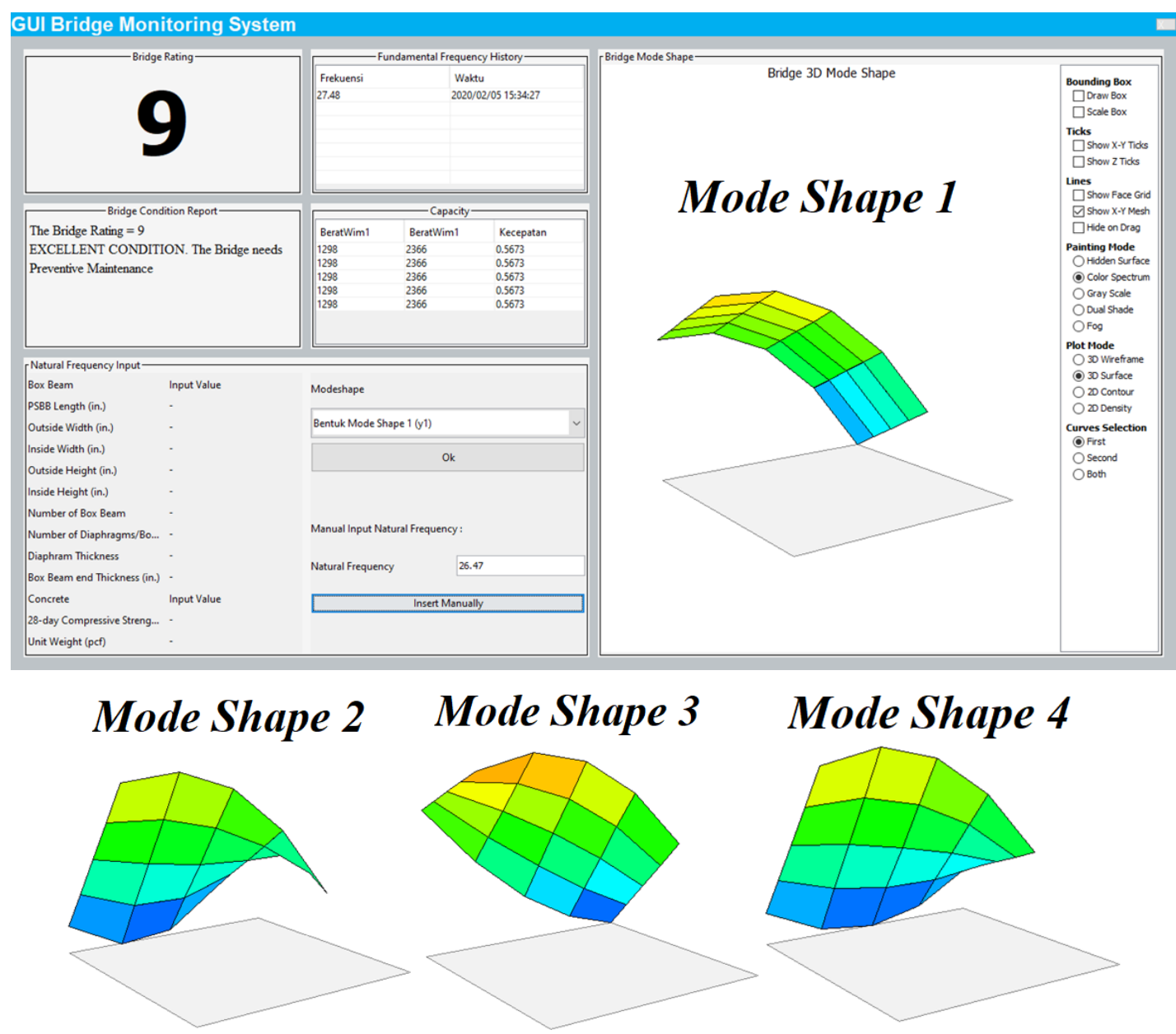

Gbr. 6 Antarmuka integrasi sistem.

hapus jembatan, cek daftar jembatan, dan monitoring. Sedangkan untuk aktor admin, terdapat fitur login, tambah pengguna, edit pengguna, hapus pengguna, dan persetujuan pengguna yang mendaftar.

Fitur paling penting pada pengujian fungsionalitas ini adalah fitur monitoring yang menampilkan hasil pengukuran jembatan. Pada fitur monitoring terdapat bagian yang menampilkan data frekuensi alamiah, berat kendaraan, nilai kesehatan jembatan, dan gambaran mode shape. Data frekuensi alamiah diperoleh dari perhitungan rata-rata frekuensi pertama yang diperoleh dari sensor pertama sampai ke- $N$, lalu nilai jembatan diperoleh dari hasil perhitungan antara frekuensi alamiah yang diperoleh saat ini dengan frekuensi alamiah jembatan ketika baru dibangun atau melalui FEA. Beban kendaraan diperoleh dari sensor load cell. Terakhir, mode shape diperoleh dari hasil perhitungan amplitudo yang dihitung oleh masing-masing sensor nirkabel. Di sini dihasilkan empat penggambaran mode shape. Antarmuka grafis dari integrasi sistem yang dikembangkan ditunjukkan pada Gbr. 6.

\section{Pengujian di Test-bed}

Pengujian dimulai dengan pemasangan sensor nirkabel SunSpot dan load cell pada jembatan test-bed, seperti diilustrasikan pada Gbr. 7. Pengujian menggunakan truk Scania 1:14 RC dengan berat $18 \mathrm{~kg}$, dengan pertimbangan berat truk
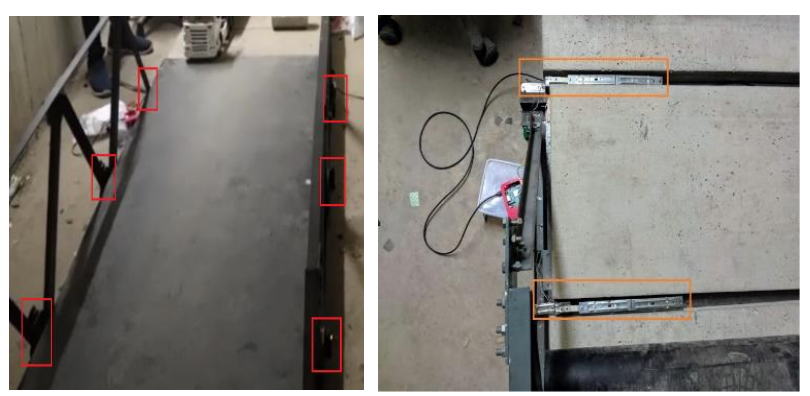

Gbr. 7 Peletakan sensor di jembatan test-bed (kotak merah) dan load cell (kotak kuning).

dapat memberikan getaran yang signifikan untuk diukur oleh sensor SunSpot. Sensor nirkabel SunSpot yang digunakan pada eksperimen ini berjumlah enam simpul dengan peletakan di bagian kiri jembatan sebanyak tiga simpul dan di bagian kanan jembatan sebanyak tiga simpul. Sensor load cell yang digunakan berjumlah dua buah dan diletakkan pada bagian awal jembatan. Setelah semua simpul sensor dipasang, truk Scania 1:14 RC melewati sensor load cell yang menyebabkan sensor menghitung berat truk dan membangunkan sensor nirkabel SunSpot. Ketika truk melewati sensor nirkabel SunSpot, pengambilan dan pemrosesan data segera dilakukan oleh sensor nirkabel SunSpot. Selanjutnya, data yang selesai 

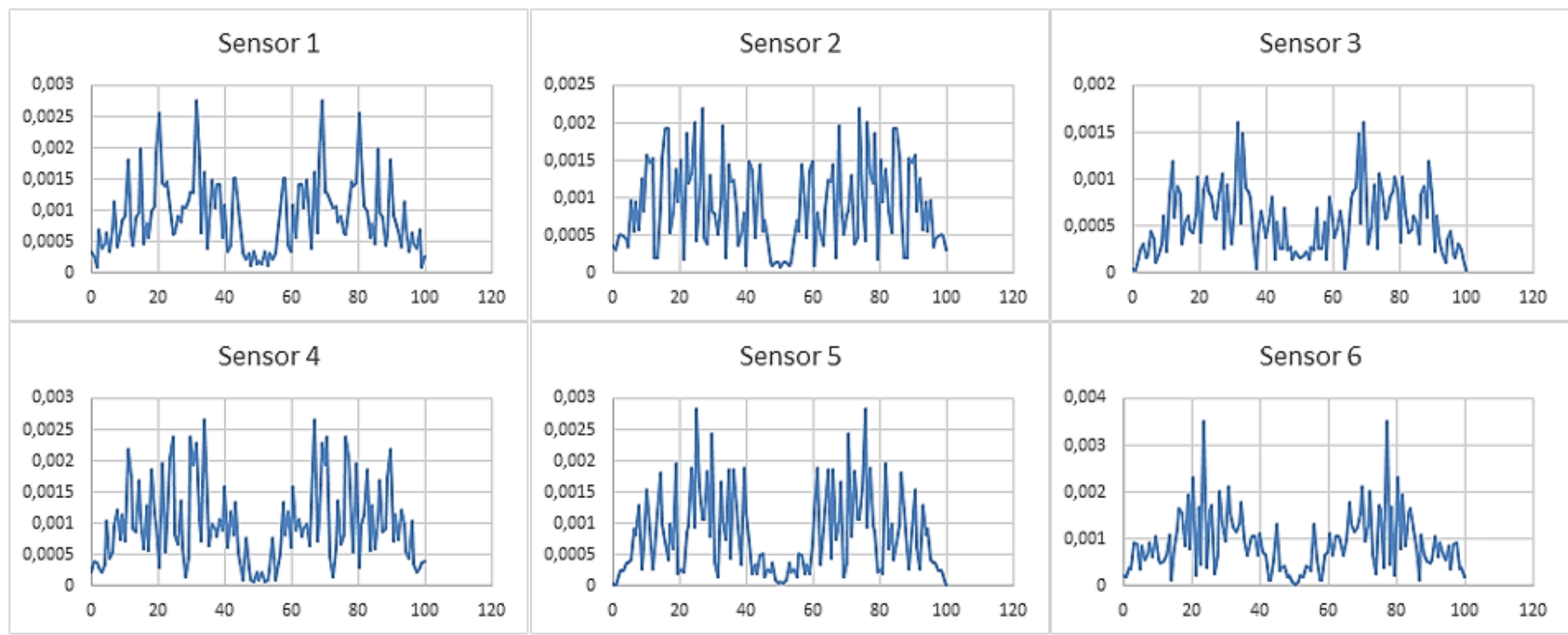

Gbr. 8 Grafik hasil FFT data mentah sensor nirkabel SunSpot.

TABEL II

HASIL DATA INTEGRASI SISTEM

\begin{tabular}{|c|c|c|c|c|}
\hline \multicolumn{5}{|c|}{ Frekuensi (Hz) } \\
\hline ID & F1 & F2 & F3 & F4 \\
\hline 1 & 29,69 & 16,41 & 14,06 & 13,28 \\
\hline 2 & 28,91 & 21,09 & 29,69 & 17,19 \\
\hline 3 & 28,13 & 29,91 & 15,19 & 26,56 \\
\hline 4 & 29,69 & 26,41 & 25,00 & 28,22 \\
\hline 5 & 25,00 & 28,28 & 22,66 & 18,5 \\
\hline 6 & 23,44 & 22,66 & 29,69 & 25,78 \\
\hline \multicolumn{5}{|c|}{ Amplitudo (m/s $\left.\mathbf{s}^{2}\right)$} \\
\hline ID & $\mathbf{A 1}$ & $\mathbf{A 2}$ & $\mathbf{A 3}$ & $\mathbf{A 4}$ \\
\hline 1 & $2,12 \times 10^{-8}$ & $6,01 \times 10^{-8}$ & $7,58 \times 10^{-8}$ & $8,10 \times 10^{-8}$ \\
\hline 2 & $2,88 \times 10^{-8}$ & $4,82 \times 10^{-8}$ & $2,31 \times 10^{-8}$ & $5,98 \times 10^{-8}$ \\
\hline 3 & $7,19 \times 10^{-8}$ & $6,14 \times 10^{-8}$ & $1,52 \times 10^{-8}$ & $4,37 \times 10^{-8}$ \\
\hline 4 & $4,46 \times 10^{-8}$ & $2,31 \times 10^{-8}$ & $5,04 \times 10^{-8}$ & $4,87 \times 10^{-8}$ \\
\hline 5 & $3,80 \times 10^{-8}$ & $1,16 \times 10^{-8}$ & $4,60 \times 10^{-8}$ & $1,49 \times 10^{-8}$ \\
\hline 6 & $6,70 \times 10^{-8}$ & $7,12 \times 10^{-8}$ & $4,05 \times 10^{-8}$ & $5,19 \times 10^{-8}$ \\
\hline
\end{tabular}

diproses dikirim ke simpul sink. Sensor-sensor nirkabel SunSpot akan kembali tidur dan data yang ada di simpul sink dikirimkan ke server aplikasi untuk disimpan di sistem basis data. Terakhir, data tersebut ditampilkan di antarmuka grafis pengguna. Tabel II menampilkan data pengukuran frekuensi alamiah jembatan. Keterangan ID menandakan ID sensor, F1 sampai F4 adalah frekuensi $(\mathrm{Hz})$, dan A1 sampai A4 adalah amplitudo $\left(\mathrm{m} / \mathrm{s}^{2}\right)$.

\section{Validasi Data}

Validasi data dilakukan menggunakan FEA sebagai acuan standar [18]. FEA ini dijadikan acuan untuk memeriksa kesesuaian data frekuensi yang dihitung oleh algoritme yang ditanam di sistem dengan data frekuensi yang dihitung menggunakan perangkat lunak MATLAB. Menurut FEA, diperoleh frekuensi alamiah jembatan test-bed sebesar 26,47 Hz.

Langkah-langkah yang diambil untuk skenario validasi adalah melakukan tes dalam miniatur menggunakan sistem yang dibuat, lalu diuji lagi dengan aplikasi pengambilan data
TABEL III

HASIL DATA SKENARIO VALIDASI

\begin{tabular}{|c|c|c|c|c|}
\hline \multicolumn{5}{|c|}{ Frekuensi (Hz) } \\
\hline ID & F1 & F2 & F3 & F4 \\
\hline 1 & 31,50 & 20,48 & 14,18 & 11,03 \\
\hline 2 & 26,77 & 24,41 & 33,86 & 16,54 \\
\hline 3 & 31,50 & 33,07 & 11,03 & 26,77 \\
\hline 4 & 33,86 & 29,93 & 24,42 & 31,50 \\
\hline 5 & 25,20 & 29,92 & 18,90 & 23,63 \\
\hline 6 & 23,63 & 20,48 & 30,71 & 28,35 \\
\hline \multicolumn{5}{|c|}{ Amplitudo $\left(\mathbf{m} / \mathbf{s}^{2}\right)$} \\
\hline ID & $\mathbf{A 1}$ & $\mathbf{A 2}$ & $\mathbf{A 3}$ & $\mathbf{A 4}$ \\
\hline 1 & $7,04 \times 10^{-8}$ & $1,55 \times 10^{-8}$ & $2,49 \times 10^{-8}$ & $3,76 \times 10^{-8}$ \\
\hline 2 & $7,77 \times 10^{-8}$ & $8,59 \times 10^{-8}$ & $4,57 \times 10^{-8}$ & $1,79 \times 10^{-8}$ \\
\hline 3 & $4,12 \times 10^{-8}$ & $3,47 \times 10^{-8}$ & $2,49 \times 10^{-8}$ & $3,74 \times 10^{-8}$ \\
\hline 4 & $5,86 \times 10^{-8}$ & $6,79 \times 10^{-8}$ & $1,01 \times 10^{-8}$ & $5,83 \times 10^{-8}$ \\
\hline 5 & $1,13 \times 10^{-8}$ & $6,89 \times 10^{-8}$ & $1,38 \times 10^{-8}$ & $8,56 \times 10^{-8}$ \\
\hline 6 & $1,60 \times 10^{-8}$ & $1,39 \times 10^{-8}$ & $5,73 \times 10^{-8}$ & $6,35 \times 10^{-8}$ \\
\hline
\end{tabular}

mentah dari sensor nirkabel SunSpot. Setelah itu, data mentah yang diperoleh diolah di perangkat lunak MATLAB untuk dilakukan FFT, sehingga diperoleh empat puncak amplitudo frekuensi. Hasil perhitungan frekuensi alamiah dari MATLAB dibandingkan dengan hasil algoritme perhitungan yang ditanam di setiap sensor nirkabel SunSpot. FFT yang diperoleh dari data mentah di setiap sensor nirkabel SunSpot digambarkan pada Gbr. 8 dan data hasil perhitungan frekuensi alamiah melalui MATLAB ditampilkan pada Tabel III.

Berdasarkan data yang ada, hasil perhitungan frekuensi oleh sistem adalah 27,48 Hz, sedangkan FEA sebesar 26,47 Hz. Di sini, nilai yang diperoleh FEA mendekati nilai yang diperoleh dari sistem pengukuran yang telah dibangun. Kemudian, dilakukan perbandingan antara data hasil pengukuran oleh sistem dengan data hasil perhitungan MATLAB untuk setiap data sensor. Terdapat perbedaan antara data hasil sistem, yaitu $27,48 \mathrm{~Hz}$, dengan hasil pengukuran MATLAB, yaitu $28,75 \mathrm{~Hz}$. Terdapat perbedaan yang kecil, yaitu sebesar 1,27 Hz, yang disebabkan tingkat ketelitian prosesor di sensor nirkabel 
TABEL IV

HASIL DATA SENSOR WIM

\begin{tabular}{|c|c|c|}
\hline Sampel & $\begin{array}{c}\text { Berat asli } \\
(\mathbf{g})\end{array}$ & $\begin{array}{c}\text { Hasil WIM } \\
(\mathbf{g})\end{array}$ \\
\hline 1 & 150 & 159 \\
\hline 2 & 150 & 152 \\
\hline 3 & 150 & 163 \\
\hline
\end{tabular}

SunSpot berbeda dengan ketelitian prosesor komputer yang menjalankan MATLAB. Namun, masih dapat disimpulkan bahwa sistem yang dibangun valid.

Pada validasi sensor WIM, dilakukan perbandingan pengukuran menggunakan timbangan dengan pengukuran sistem. Menurut pengukuran timbangan, berat asli sebuah benda sebesar $150 \mathrm{~g}$, sedangkan beban yang dicoba pada load cell sebesar 159 g. Jadi, dapat disimpulkan bahwa nilai yang diukur pada sensor WIM mendekati nilai asli berat yang diuji, dengan kesalahan kurang lebih 0,02\%-0,09\%. Tabel IV menampilkan data hasil dari WIM.

\section{Perbandingan dengan Penelitian Terdahulu}

Penelitian-penelitian sebelumnya memiliki kekurangan antara lain belum ada mekanisme pengaktifan sensor, sehingga sensor selalu hidup dan boros energi. Selain itu, penelitian sebelumnya belum dapat mengidentifikasi berat dan laju kendaraan sebagai fitur dalam mengawasi lalu lintas di jembatan. Kekurangan tersebut diperbaiki di makalah ini dengan penambahan WIM sebagai simpul yang mengendalikan kerja sensor nirkabel SunSpot supaya bekerja ketika jembatan dilewati kendaraan berat saja.

Jika dibandingkan dengan penelitian sebelumnya, kelebihan sistem yang berhasil dikembangkan adalah sebagai berikut.

- Pada penelitian sebelumnya, sensor SunSpot terus menyala, sedangkan pada sistem yang dikembangkan, sensor SunSpot berada pada kondisi sleep ketika tidak ada kendaraan melintas. Mode sensor nirkabel ini dapat diubah kondisinya menjadi wake up untuk melakukan pengindraan ketika ada kendaraan berat yang melintas. Mekanisme ini bermanfaat untuk menghemat energi sensor.

- Pada penelitian sebelumnya, mode shape digambarkan berdasarkan satu frekuensi alamiah saja. Hal ini menghasilkan satu gambar mode shape. Pada sistem yang dikembangkan, mode shape dapat digambarkan dalam empat bentuk berbeda berdasarkan empat frekuensi alamiah jembatan.

- Pada sistem yang dikembangkan dapat ditampilkan data berat dan laju kendaraan yang melintas pada jembatan.

Makalah ini masih menyisakan kelemahan pada pemasangan load cell yang tidak praktis karena harus melakukan penggalian aspal jalan. Solusi untuk kelemahan ini adalah penggunaan WIM berbasis piezoelektrik sebagai alternatif yang penggunaannya tidak memerlukan penggalian aspal yang terlalu dalam.

\section{KESIMPULAN}

Pada makalah ini telah dilakukan integrasi sistem pengawasan penilaian kesehatan jembatan berbasis WSN dengan sistem pengawasan lalu lintas berbasis WIM. Integrasi dilakukan dengan mengembangkan sensor load cell sebagai sensor pengambil data berat kendaraan dan sebagai sensor yang memberi tanda kepada sensor nirkabel SunSpot untuk bangun dari tidurnya dan melakukan pengindraan. Pengembangan ini bertujuan agar sensor nirkabel SunSpot hemat dalam penggunaan baterai. Sistem telah berhasil diintegrasikan dengan dihasilkannya fitur yang dapat menampilkan berat dan laju kendaraan, sensor nirkabel SunSpot berhasil mengambil frekuensi alamiah dominan jembatan, sistem dapat melakukan perhitungan nilai kesehatan jembatan, dan sistem berhasil menampilkan mode shape. Pengukuran sistem yang diintegrasikan menghasilkan perhitungan nilai frekuensi alamiah yang mendekati hasil perhitungan FEA. Hal ini berarti sistem valid mengukur frekuensi alamiah jembatan. Kemudian, hasil pengukuran WIM mendekati nilai berat yang diuji dengan timbangan acuan, dengan kesalahan kurang lebih dari 0,02\%$0,09 \%$.

Penelitian berikutnya akan difokuskan pada implementasi di jembatan SDOF nyata dengan memanfaatkan WIM berbasis piezoelektrik. Optimasi jumlah simpul sensor nirkabel beserta optimasi pemasangannya juga akan dijadikan pertimbangan.

\section{UCAPAN TERIMA KASIH}

Terima kasih disampaikan kepada Pembimbing Penelitian, Jurusan Sistem Informasi Telkom University, pengurus Laboratorium Rekayasa Struktur Fakultas Teknik Sipil ITB, dan Newton Fund yang telah mendanai penelitian ini.

\section{REFERENSI}

[1] J.A.C. Tokognon, B. Gao, G.Y. Tian, dan Y. Yan, "Structural Health Monitoring Framework Based on Internet of Things: A Survey," IEEE Internet of Things Journal, Vol. 7, No. 4, hal. 4-7, 2017.

[2] T. Böhm, C. Lackhove, dan M. Meyer zu Hörste, "Integrated Traffic Management using Data from Traffic, Asset Conditions, Energy and Emissions," dalam Handbook of Research on Emerging Innovations in Rail Transportation Engineering, B.U. Rai, Ed. Hershey, USA: IGI Global, 2016, hal. 405-419.

[3] Z. Alam, G. Wang, J. Cao, dan J. Wu, "Deploying Wireless Sensor Network with Fault-Tolerance for Structural Health Monitoring," IEEE Transaction on Computer, Vol. 64, No. 2, hal. 382-395, 2015.

[4] E. Sazonov, H. Li, D. Curry, dan P. Pillay, "Self-Powered Sensor for Monitoring of Highway Bridges," IEEE Sensor Journal, Vol. 9, No. 11, hal. 1422-1429, 2009.

[5] Z. Zou, Y. Bao, F. Deng, dan H. Li, "An Approach of Reliable Data Transmission with Random Redundancy for Wireless Sensors in Structural Health Monitoring," IEEE Sensors Journal, Vol. 15, No. 2, hal. 809-818, 2015.

[6] S. Kim, J. Lee, M.S. Park, dan B.W. Jo, "Vehicle Signal Analysis Using Artificial Neural Networks for a Bridge Weigh-in-Motion System," IEEE Sensors Journal, Vol. 9, No. 10, hal. 7943-7956, 2009.

[7] A. Araujo, J. García-Palacios, J. Blesta, F. Tirado, dan E. Romero, "Wireless Measurement System for Structural Health Monitoring With High Time-Synchronization Accuracy," IEEE Transactions on Instrumentation and Measurement, Vol. 61, hal. 801-810, 2012.

[8] D. Mascareñas, E. Flynn, C. Farrar, G. Park, dan M. Todd, "A Mobile Host Approach for Wireless Powering and Interrogation of Structural Health Monitoring Sensor Networks," IEEE Sensors Journal, Vol. 9, No. 12, hal. 1719-1726, 2009.

[9] R. Bajwa, "Wireless Weigh-In_Motion: Using Road Vibratiob to Estimate Truck Weights," Ph.D. Thesis, Electrical Engineering and Computer Sciences University of California, Berkeley, USA, 2013. 
[10] S.M. Khan, S. Atamturktur, M. Chowdhury, dan M. Rahman, "Integration of Structural Health Monitoring and Intelligent Transportation Systems for Bridge Condition Assessment: Current Status and Future Direction," IEEE Transactions on Intelligent Transportation Systems, Vol. 17, No. 8, hal. 2107-2122, 2016.

[11] J. Gajda, R. Sroka, M. Stencel, T. Zeglen, P. Piwowar, P. Burnos, dan Z. Marszalek, "Design and Accuracy Assessment of the Multi-sensor Weigh-in-Motion System," IEEE Instrumentation and Measurement Technology Conference (I2MTC), 2015, hal. 1036-1041.

[12] K. Kondratjevs, N. Kunicina, A. Patlins, A. Zabasta, dan A. Galkina, "Vehicle Weight Detection Sensor Development for Data Collecting in Sustainable City Transport System," 57th International Scientific Conference on Power and Electrical Engineering of Riga Technical University (RTUCON), 2016, hal. 1-5.

[13] Z. Zhang, Y. Huang, R. Bridgelall, M. Al-Tarawneh, dan P. Lu, "Optimal System Design for Weigh-In-Motion Measurements Using InPavement Strain Sensors," IEEE Sensors Journal, Vol. 17, No. 23, hal. 7677-7684, 2017.

[14] M.J. Chae, H.S. Yoo, J.Y. Kim, dan M.Y. Cho, "Development of a Wireless Sensor Network System for Suspension Bridge Health Monitoring," Automation in Construction, Vol. 21, No. 1, hal. 237-252, 2012 .
[15] X. Hu, B. Wang, dan H. Ji, "A Wireless Sensor Network-Based Structural Health Monitoring System for Highway Bridges," ComputerAided Civil and Infrastructure Engineering, Vol. 28, No. 3, hal. 193-209, 2013.

[16] A.B. Noel, A. Abdaoui, T. Elfouly, M.H. Ahmed, A. Badawy, dan M.S. Shehata, "Structural Health Monitoring Using Wireless Sensor Networks: A Comprehensive Survey," IEEE Communications Surveys and Tutorials, Vol. 19, No. 3, hal. 1403-1423, 2017.

[17] A.A. Islam, F. Li, H. Hamid, dan A. Jaroo, "Bridge Condition Assessment and Load Rating Using Dynamic Response," YoungsTown State University, Ohio, USA, Final Report 134695, 2014.

[18] S.A. Putra, G.A.A. Sani, A.T. Nurwijaya, A. Anandadiga, P.B. Wijayanto, B.R. Trilaksono, dan M. Riyansyah, "Sistem Penilaian Kondisi Jembatan Menggunakan Respons Dinamik dengan Wireless Sensor Network," Jurnal Nasional Teknik Elektro dan Teknologi Informasi (JNTETI), Vol. 7, No. 3, hal. 338-343, 2018.

[19] A.M. de Souza, C.A.R.L. Brennand, R.S. Yokoyama, E.A. Donato, E.R.M. Madeira, dan L.A. Villas, "Traffic Management Systems: A Classification, Review, Challenges, and Future Perspectives," International Journal of Distributed Sensor Networks, Vol. 13, No. 4, hal. 1-14, 2017. 